\title{
ARAH DAN KEBIJAKAN PERATURAN OTORITAS JASA KEUANGAN NOMOR 15/POJK.04/2015 TENTANG PENERAPAN PRINSIP SYARIAH DI PASAR MODAL
}

\author{
Heris Suhendar \\ Program Pasca Sarjana UIN Sunan Gunung Djati Bandung \\ Jl. A. H. Nasution Nomor 105 Bandung \\ Email: herissuhendar@gmail.com
}

\begin{abstract}
Abstrak
Sejak tahun 1997, pasar modal syariah Indonesia terus tumbuh dan berkembang yang ditandai dengan semakin banyaknya produk syariah, terbitnya regulasi terkait pasar modal syariah, dan semakin bertambahnya masyarakat yang mengenal dan peduli pasar modal syariah. Peraturan terkait pasar modal syariah diterbitkan pertama kali pada tahun 2006, yaitu Peraturan No. IX.A.13 tentang Penerbitan Efek Syariah dan Peraturan No. IX.A.14 tentang Akad-akad yang Digunakan dalam Penerbitan Efek. Selanjutnya pada tahun 2007 diterbitkan Peraturan No. II.K.1 tentang Kriteria dan Penerbitan Daftar Efek Syariah. Seluruh peraturan tersebut memuat ketentuan khusus terkait dengan pemenuhan prinsip syariah di pasar modal yang diadopsi dari fatwa Dewan Syariah Nasional (DSN). Kemudian pada tahun 2015, Otoritas Jasa Keuangan mengeluarkan Peraturan Nomor 15/P0JK.04/2015 terkait dengan Penerapan Prinsip Syariah di Pasar Modal. Peraturan OJK tersebut mengarah kepada: 1) penguatan kerangka hukum untuk penerbitan efek syariah; 2) mengupayakan insentif untuk produk syariah; 3) memperkuat peran pelaku pasar di pasar modal syariah; dan 4) memperkuat landasan hukum bagi transaksi efek syariah. Pada saat Peraturan Otoritas Jasa Keuangan ini mulai berlaku, angka 1 Peraturan Nomor IX.A.13 tentang Penerbitan Efek Syariah, Lampiran Keputusan Ketua Badan Pengawas Pasar Modal dan Lembaga Keuangan Nomor: Kep-181/BL/2009 tanggal 30 Juni 2009 tentang Penerbitan Efek Syariah dicabut dan dinyatakan tidak berlaku.
\end{abstract}

\section{Kata Kunci:}

Efek Syariah, Fatwa DSN, Pasar Modal Syariah 


\section{A. Pendahuluan}

Pasar modal syariah ${ }^{1}$ di Indonesia telah berkembang selama dua dekade, yaitu dimulai sejak pertama kali diluncurkannya reksa dana syariah pada tahun 1997.2 Reksa dana di Inggris dikenal dengan sebutan unit trust (saham) yang didasarkan atas kepercayaan, di Amerika dikenal dengan istilah mutual fund (dana bersama), sedangkan di Jepang dikenal dengan istilah investmen fund (pengelolaan dana untuk investasi berdasarkan kepercayaan. ${ }^{3}$ Secara bahasa, reksa dana tersusun atas dua konsep yang berbeda namun keduanya tidak bisa dipisahkan, yaitu reksa (menjaga atau memelihara) dan dana (himpunan modal dalam bentuk uang). ${ }^{4}$ Sedangkan pengertian reksa dana menurut peraturan perundang-undangan di Indonesia 5 adalah wadah yang digunakan untuk menghimpun dana dari masyarakat pemodal untuk selanjutnya diinvestasikan dalam bentuk portofolio efek oleh manajer investasi atau

1 Menurut beberapa ahli, yang dimaksud dengan pasar modal yaitu: 1) Tjipto Darmadji, dkk adalah pasar untuk berbagai instrumen keuangan jangka panjang yang bisa diperjualbelikan baik dalam bentuk utang ataupun modal sendiri. Lihat Tjipto Darmadji, dkk, Pasar Modal di Indonesia (Jakarta: Salemba Empat. 2000), hlm. 1.; 2) Dahlan Siamat, pasar modal dalam arti sempit adalah suatu tempat yang terorganisasi di mana efek-efek diperdagangkan yang disebut Bursa Efek. Lihat Dahlan Siamet, Manajemen Lembaga Keuangan (Jakarta: Lembaga Penerbit Fakultas Ekonomi Universitas Indonesia. 2004), hlm. 249.; dan 3) Y. Sri Susilo, dkk menyebutkan bahwa pasar modal adalah (capital market) adalah pasar keuangan untuk dana-dana jangka panjang dan merupakan pasar yang konkret. Lihat Y. Sri Susilo, dkk, Bank dan Lembaga Keuangan Lain (Jakarta: Salemba Empat. 2004), hlm. 189. Sedangkan pasar modal syariah secara sederhana dapat diartikan sebagai pasar modal yang menerapkan prinsip-prinsip syariah dalam kegiatan transaksi ekonomi dan terlepas dari unsur-unsur yang dilarang seperti: riba, perjudian, spekulasi, dan lain-lain. Lihat Andri Soemitra, Bank dan Lembaga Keuangan Syariah (Jakarta: Kencana. 2014), hlm. 111. Setidaknya terdapat tiga mekanisme kegiatan yang perlu diperhatikan dalam pasar modal syariah sehingga tidak melanggar prinsip-prinsip ke-syariahannya, yaitu: 1) mengenai emiten; 2) jenis efek yang diperdagangkan; dan 3) mekanisme perdagangannya. Lihat Fatwa DSN Nomor 40/DSN-MUI/X/2003 tentang Pasar Modal dan Pedoman Umum Penerapan Syariah di Bidang Pasar Modal.

2 Tim Penyusun Direktorat Pasar Modal Syariah Otoritas Jasa Keuangan, Roadmap Pasar Modal Syariah 2015-2019 (Jakarta: Direktorat Pasar Modal Syariah Otoritas Jasa Keuangan. 2015), hlm. 13.

3 Jaka E. Cahyono, Cara Jitu Memilih Untung dari Reksa Dana (Jakarta: Elex Media Komputindo. 2000), hlm. 16.

4 Berdasarkan kedua konsep tersebut dapat dipahami bahwa reksa dana merupakan kumpulan modal dalam bentuk uang yang dipelihara atau dijaga. Lihat Asri Sitompul, Reksa Dana: Pengantar dan Pengenalan Umum (Bandung: Cintra Aditya Bakti. 2000), hlm. 2.

${ }^{5}$ Dari definisi tersebut, paling tidak terdapa tiga unsur penting dalam reksa dana, yaitu: 1) kumpulan dana; 2) portofolio efek; dan 3) manajer investasi sebagai pengelola dana. Lihat Pasal 1 ayat (23) Undang-Undang Nomor 8 Tahun 1995 tentang Pasar Modal. 
lebih dikenal dengan sebutan MI. Kemudian pengertian reksa dana syariah sendiri menurut Fatwa Dewan Syariah Nasional adalah reksana dana yang beroperasi menurut ketentuan dan prinsip syariah, baik dalam bentuk akad antara pemilik modal dengan manajer investasi sebagai wakil, maupun antara manajer investasi sebagai wakil atas pemilik modal dengan pengguna investasi (perusahaan). ${ }^{6}$

Sejak tahun 1997, pasar modal syariah Indonesia terus tumbuh dan berkembang yang ditandai dengan semakin banyaknya produk syariah, diterbitkannya regulasi terkait pasar modal syariah, dan semakin bertambahnya masyarakat yang mengenal dan peduli pasar modal syariah. Produk syariah yang tersedia hingga akhir 2014 terdiri dari efek syariah berupa saham syariah, obligasi syariah, reksa dana syariah Kontrak Investasi Kolektif Efek Beragun Aset (KIK EBA) Syariah, dan surat berharga lainnya yang sesuai dengan prinsip-prinsip syariah.7 Indonesia telah memiliki regulasi pasar modal syariah yang didasarkan

${ }^{6}$ Fatwa ialah suatu perkataan dari bahasa Arab yang memberi arti pernyataan hukum mengenai sesuatu masalah yang timbul kepada siapa yang ingin mengetahuinya. Sedangkan Dewan Syariah Nasional (DSN) adalah Dewan yang dibentuk oleh Majelis Ulama Indonesia untuk menangani masalah-masalah yang berhubungan dengan aktivitas lembaga keuangan syariah. Lihat Tim Penyunting, Himpunan Fatwa Keuangan Syariah (Dewan Syariah Nasional MUI) (Jakarta: Erlangga. 2014), hlm. 4 dan 7. Lihat juga Fatwa Dewan Syariah Nasional Nomor 20/DSN-MUI/IX/2000 tentang Pedoman Pelaksanaan Investasi untuk Reksa Dana Syariah.

${ }^{7}$ Efek Syariah adalah efek sebagaimana dimaksud dalam peraturan perundang undangan di bidang Pasar Modal adalah surat berharga yang akad, pengelolaan perusahaannya, maupun cara penerbitannya memenuhi Prinsip-prinsip Syariah, yang mencakup: 1) Saham Syariah adalah bukti kepemilikan atas suatu perusahaan yang memenuhi kriteria sebagaimana tercantum dalam pasal 3, dan tidak termasuk saham yang memiliki hak-hak istimewa; 2) Obligasi Syariah adalah surat berharga jangka panjang berdasarkan Prinsip Syariah yang dikeluarkan Emiten kepada pemegang Obligasi Syariah yang mewajibkan Emiten untuk membayar pendapatan kepada pemegang Obligasi Syariah berupa bagi hasil/margin/fee serta memb ayar kembali dana obligasi pada saat jatuh tempo; 3) Reksa Dana Syariah adalah Reksa Dana yang beroperasi menurut ketentuan dan prinsip Syariah Islam, baik dalam bentuk akad antara pemodal sebagai pemilik harta (shahib al-mal/rabb al-mal) dengan Manajer Investasi, begitu pula pengelolaan dana investasi sebagai wakil shahib al-mal, maupun antara Manajer Investasi sebagai wakil shahib almal dengan pengguna investasi; 4) Efek Beragun Aset Syariah adalah Efek yang diterbitkan oleh kontrak investasi kolektif EBA Syariah yang portofolio-nya terdiri dari aset keuangan berupa tagihan yang timbul dari surat berharga komersial, tagihan yang timbul di kemudian hari, jual beli pemilikan aset fisik oleh lembaga keuangan, Efek bersifat investasi yang dijamin oleh pemerintah, sarana peningkatan investasi/arus kas serta aset keuangan setara, yang sesuai dengan Prinsip-prinsip Syariah; dan 5) Surat berharga komersial Syariah adalah surat pengakuan atas suatu pembiayaan dalam jangka waktu tertentu yang sesuai dengan Prinsip-prinsip syariah. Lihat Fatwa DSN Nomor 40/DSN-MUI/X/2003 tentang Pasar Modal dan Pedoman Umum Penerapan Syariah di Bidang Pasar Modal. 
pada fatwa yang diterbitkan oleh Dewan Syariah Nasional - Majelis Ulama Indonesia (DSN-MUI) Nomor 40/DSN-MUI/X/2003 tentang Pasar Modal dan Pedoman Umum Penerapan Syariah di Bidang Pasar Modal. Selain itu, sosialisasi dan edukasi tentang pasar modal syariah juga semakin banyak dilakukan, baik melalui pendidikan formal atau sosialisasi dengan menggunakan media informasi maupun media lainnya.

Perkembangan pasar modal syariah yang telah dicapai tersebut merupakan hasil kerja keras regulator dan seluruh pemangku kepentingan dalam mengimplementasikan strategi pengembangan pasar modal syariah yang tertuang dalam Master Plan Pasar Modal dan Industri Keuangan Non Bank 2010-2014 serta Master Plan Pasar Modal 20052009. Perkembangan pasar modal syariah selama 20 tahun tersebut patut diapresiasi. Namun demikian, mengingat bahwa market share produk syariah di pasar modal yang masih relatif kecil, maka diperlukan strategi pengembangan yang terencana untuk mewujudkan pasar modal syariah yang memberikan kontribusi signifikan bagi perekonomian nasional, berkeadilan, dan melindungi kepentingan masyarakat. Beberapa hal yang memerlukan pengembangan lebih lanjut adalah aspek regulasi, produk, sumber daya manusia, serta teknologi informasi. Selain itu, promosi dan edukasi mengenai pasar modal syariah juga perlu mendapatkan perhatian yang lebih besar.

Terkait dengan regulasi, Indonesia saat ini telah memiliki beberapa peraturan serta fatwa yang melandasi kegiatan pasar modal syariah. Namun demikian, masih perlu disusun peraturan lain agar dapat memacu perkembangan pasar modal syariah secara optimal. Selanjutnya, untuk mendukung semua hal di atas perlu adanya koordinasi dengan pemerintah dan regulator lain baik dari internal maupun eksternal 0JK. Koordinasi ini diharapkan menghasilkan sinergi kebijakan yang dapat mempercepat pencapaian hal-hal yang diharapkan dalam pengembangan pasar modal syariah.

\section{B. Latar Belakang Dikeluarkannya POJK tentang Pasar Modal Syariah}

Dalam rangka mewujudkan pasar modal syariah yang tumbuh, stabil, berkelanjutan, dan akuntabel, OJK telah menetapkan 5 (lima) arah pengembangan pasar modal syariah untuk periode 2015-2019. Untuk mencapai sasaran yang diinginkan, arah pengembangan tersebut 
dijabarkan dalam program kerja dan rencana aksi, sebagaimana terlihat pada Bagan di bawah ini: 8

Bagan. 1.

Arah Pengembangan Pasar Modal Syariah

Penguatan Pengaturan atas Produk, Lembaga, dan

Profesi Terkait Pasar Modal Syariah

1. Memperkuat Kerangka Hukum untuk Penerbitan Efek Syariah

Dengan dikeluarkannya POJK tentang Pasar Modal Syariah dapat memperjelas aturan mengenai hak dan kewajiban setiap pihak yang terlibat dalam transaksi pasar modal syariah.

\section{Mengupayakan Insentif untuk Produk Syariah}

Program ini dilaksanakan dengan mengupayakan insentif dalam penerbitan efek syariah antara lain potongan biaya perizinan, biaya pendaftaran, dan biaya tahunan, relaksasi pengaturan bagi reksa dana syariah, serta mengupayakan quick win untuk penyelesaian proses pernyataan pendaftaran produk syariah.

3. Memperkuat Peran Pelaku Pasar di Pasar Modal Syariah Program ini dilaksanakan dengan menerbitkan aturan terkait ahli syariah pasar modal (ASPM) yang melakukan kegiatan di pasar modal serta aturan terkait penerapan prinsip syariah di lembaga penunjang pasar modal dan perusahaan efek.

4. Memperkuat Landasan Hukum bagi Transaksi Efek Syariah

Program ini dilaksanakan dengan melakukan kajian dalam rangka menyusun regulasi untuk transaksi efek syariah di pasar sekunder.

8 Tim Penyusun Direktorat Pasar Modal Syariah Otoritas Jasa Keuangan, Roadmap Pasar Modal Syariah 2015-2019. hlm. 15. 
Peraturan terkait pasar modal syariah diterbitkan pertama kali pada tahun 2006, yaitu Peraturan No. IX.A.13 tentang Penerbitan Efek Syariah $^{9}$ dan Peraturan No. IX.A.14 tentang Akad-akad yang Digunakan dalam Penerbitan Efek Syariah ${ }^{10}$ yang ditetapkan di Jakarta pada tanggal 23 Nopember 2016 oleh Ketua Badan Pengawas Pasar Modal dan Lembaga Keuangan (Ketua BAPEPAM dan LK) A. Fuad Rahmany. Selanjutnya pada tahun 2007 diterbitkan Peraturan No. II.K.1 tentang Kriteria dan Penerbitan Daftar Efek Syariah.11 Seluruh peraturan tersebut

${ }^{9}$ Lampiran Keputusan tersebut memuat: 1) Definisi operasional; 2) Ketentuan umum; 3) Penerbitan Efek Syariah berupa saham oleh Emiten atau Perusahaan Publik yang menyatakan bahwa kegiatan usaha serta cara pengelolaan usahanya dilakukan berdasarkan Prinsip-prinsip Syariah di Pasar Modal; 4) Penerbitan Sukuk; 5) Penerbitan Efek Reksa Dana Syariah; 6) Penerbitan Efek Beragun Aset (EBA) Syariah; dan 7) Dengan tidak mengurangi ketentuan pidana di bidang Pasar Modal, Bapepam dan LK dapat mengenakan sanksi terhadap setiap pelanggaran ketentuan peraturan ini, termasuk Pihak yang menyebabkan terjadinya pelanggaran tersebut.

10 Dalam peraturan ini dijelaskan, bahka akad-akad yang digunakan dalam penerbitan efek syariah di pasar modal yaitu: 1) Ijarah adalah perjanjian (akad) dimana Pihak yang memiliki barang atau jasa (pemberi sewa atau pemberi jasa) berjanji kepada penyewa atau pengguna jasa untuk menyerahkan hak penggunaan atau pemanfaatan atas suatu barang dan atau memberikan jasa yang dimiliki pemberi sewa atau pemberi jasa dalam waktu tertentu dengan pembayaran sewa dan atau upah ( ujrah), tanpa diikuti dengan beralihnya hak atas pemilikan barang yang menjadi obyek Ijarah; 2) Kafalah adalah perjanjian (akad) dimana Pihak penjamin (kafiil/guarantor) berjanji memberikan jaminan kepada Pihak yang dijamin (makfuul 'anhu/ashil/debitur) untuk memenuhi kewajiban Pihak yang dijamin kepada Pihak lain (makfuul lahu/kreditur); 3) Mudharabah (qiradh) adalah perjanjian (akad) dimana Pihak yang menyediakan dana (Shahib al-mal) berjanji kepada pengelola usaha (mudharib) untuk menyerahkan modal dan pengelola (mudharib) berjanji untuk mengelola modal tersebut; dan 4) Wakalah adalah perjanjian (akad) dimana Pihak yang memberi kuasa (muwakkil) memberikan kuasa kepada Pihak yang menerima kuasa (wakil) untuk melakukan tindakan atau perbuatan tertentu.

11 Daftar Efek Syariah adalah kumpulan Efek yang tidak bertentangan dengan Prinsip-prinsip Syariah di Pasar Modal, yang ditetapkan oleh Bapepam dan LK atau Pihak lain yang diakui oleh Bapepam dan LK. Efek yang dapat dimuat dalam Daftar Efek Syariah meliputi: 1) Surat berharga syariah yang diterbitkan oleh Negara Republik Indonesia; 2) Efek yang diterbitkan oleh Emiten atau Perusahaan Publik yang menyatakan bahwa kegiatan usaha serta cara pengelolaan usahanya dilakukan berdasarkan Prinsip-prinsip Syariah di Pasar Modal sebagaimana tertuang dalam anggaran dasar Emiten atau Perusahaan Publik; 3) Sukuk yang diterbitkan oleh Emiten atau Perusahaan Publik termasuk Obligasi Syariah yang telah diterbitkan oleh Emiten atau Perusahaan Publik sebelum ditetapkannya Peraturan ini; 4) Efek Beragun Aset (EBA) Syariah; 5) Efek berupa saham, termasuk Hak Memesan Efek Terlebih Dahulu (HMETD) Syariah dan Waran Syariah, yang diterbitkan oleh Emiten atau Perusahaan Publik yang tidak menyatakan bahwa kegiatan usaha serta cara pengelolaan usahanya dilakukan berdasarkan Prinsip-prinsip Syariah di Pasar Modal. Lihat Lampiran Peraturan No. II.K.1 tentang Kriteria dan Penerbitan Daftar Efek Syariah. 
memuat ketentuan khusus terkait dengan pemenuhan prinsip syariah di pasar modal yang diadopsi dari fatwa Dewan Syariah Nasional (DSN).

Dengan berkembangnya pasar modal syariah, Peraturan No. IX.A.13 dan Peraturan No. IX.A.14 mengalami penyempurnaan pada tahun 2009, dan pada tahun 2012 Peraturan No. II.K.1 juga disempurnakan. Selanjutnya pada tahun 2014, OJK kembali melakukan revisi atas Peraturan No. IX.A.13 dan menyusun rancangan peraturan terkait Ahli Syariah Pasar Modal. Penyempurnaan Peraturan No. IX.A.13 dilakukan dalam rangka memperjelas substansi aturan dan memberikan relaksasi bagi penerbitan efek syariah. Di samping itu, revisi Peraturan No. IX.A.13 membagi peraturan tersebut menjadi beberapa rancangan peraturan, yaitu rancangan peraturan yang terkait penerapan prinsip syariah di pasar modal, penerbitan saham syariah, sukuk, reksa dana syariah, dan efek beragun syariah.

Dalam rangka mendukung pengembangan pasar modal syariah, diperlukan penerbitan peraturan yang akan memperkuat kerangka regulasi untuk mendorong perkembangan pasar modal syariah yang lebih pesat. Terkait dengan hal tersebut, Roadmap ini telah menetapkan arah pengembangan pasar modal syariah berupa "Penguatan Pengaturan atas Produk, Lembaga, dan Profesi Terkait Pasar Modal Syariah". Arah pengembangan tersebut dilakukan melalui 4 (empat) program berikut. ${ }^{12}$

\section{Memperkuat Kerangka Hukum untuk Penerbitan Efek Syariah}

Dalam rangka mengikuti dinamika pasar dan memberikan kepastian hukum, serta meningkatkan kepercayaan pasar guna mempercepat pertumbuhan efek syariah, perlu adanya penguatan kerangka hukum pasar modal syariah. Penguatan kerangka hukum tersebut antara lain dalam bentuk penyempurnaan peraturan yang ada maupun penerbitan peraturan baru. OJK melakukan penyempurnaan terhadap Peraturan No. IX.A.13 sesuai dengan kebutuhan dan untuk menyesuaikan dengan dinamika pasar. Di samping itu juga dilakukan penyusunan peraturan baru tentang ahli syariah pasar modal. Dalam kurun waktu lima tahun yang akan datang, OJK juga akan menerbitkan aturan baru terkait produk syariah baru serta transaksi efek syariah di pasar sekunder. 
Terkait dengan hal tersebut, untuk memperkuat kerangka hukum dalam penerbitan efek syariah perlu diwujudkan rencana aksi sebagai berikut:

1) Penerbitan aturan tentang status hak dan kewajiban setiap pihak atas underlying asset ${ }^{13}$ sukuk. Penyempurnaan Peraturan No. IX.A.13 tentang Penerbitan Efek Syariah mencakup pengaturan mengenai underlying asset yang merupakan hal penting dalam penerbitan sukuk. Sebagai dasar penerbitan sukuk, underlying asset sukuk harus memenuhi prinsip syariah dan dipastikan eksistensinya hingga akhir jatuh tempo sukuk. Apabila sukuk tidak lagi memiliki underlying asset atau underlying asset yang digunakan telah berubah menjadi tidak lagi sesuai dengan prinsip syariah, maka wali amanat sebagai wakil dari investor wajib mengambil tindakan yang diperlukan untuk mendapatkan hak investor atas sukuk. Terkait dengan hal tersebut, pengaturan tentang kontrak perwaliamanatan sukuk perlu disempurnakan dengan menambahkan ketentuan antara lain mengenai hal-hal yang terkait dengan informasi tentang underlying asset, dan kewajiban wali amanat untuk mengambil tindakan yang diperlukan jika underlying asset sukuk tidak memenuhi kondisi sebagaimana dipersyaratkan. Dengan pengaturan underlying asset secara detil, hak dan kewajiban investor akan lebih jelas sehingga investor merasa lebih nyaman dalam berinvestasi pada efek syariah khususnya sukuk.

2) Kajian mengenai kontrak perwaliamanatan sukuk. Dalam penerbitan sukuk, kontrak perwaliamanatan mengacu pada peraturan perwaliamanatan untuk penerbitan obligasi dan beberapa hal yang terkait perwaliamanatan sukuk yang diatur dalam Peraturan No. IX.A.13. Hal ini dikarenakan saat ini belum terdapat peraturan khusus yang secara komprehensif mengatur kontrak perwalimanatan sukuk. Berdasarkan masukan dari pemangku kepentingan diperlukan peraturan yang komprehensif terkait dengan perwali-

13 Underlying Asset adalah aset yang menjadi dasar dalam penerbitan sukuk, yang terdiri dari: 1) aset berwujud tertentu; 2) nilai manfaat atas aset berwujud tertentu baik yang sudah ada maupun yang akan ada; 3 ) jasa yang sudah ada maupun yang akad a da; 4) aset proyek tertentu; dan/atau 5) kegiatan investasi yang telah ditentukan. Lihat Pasal 1 ayat (2) Draft Peraturan Otoritas Jasa Keuangan Nomor ......./POJK.04/2014 tentang Penerbitan Sukuk. Sedangkan sukuk adalah surat berharga negara yang diterbitkan berdasarkan prinsip syariah, sebagai bukti atas bagian kepemilikan aset Surat Berharga Syariah Negara (SBSN), baik dalam mata uang rupiah maupun valuta asing. Lihat Fatwa Dewan Syariah Nasional Nomor 69/DSN-MUI/VI/2008 tentang Surat Berharga Syariah Negara. 
amanatan sukuk. Oleh karena itu, perlu dilakukan suatu kajian untuk mengidentifikasi urgensi pengaturan perwalimanatan sukuk secara khusus dan hal-hal yang perlu diatur secara detil dalam kontrak perwaliamanatan sukuk.

3) Perluasan basis investor sukuk melalui penerbitan reksa dana berbasis sukuk. Sampai dengan saat ini sebagian besar pihak yang menjadi pemegang sukuk adalah investor institusi. Hal ini dikarenakan nilai denominasi sukuk dalam nominal yang besar sehingga tidak terjangkau oleh investor ritel. Dalam revisi peraturan IX.A.13, dimunculkan produk reksa dana syariah baru yaitu reksadana berbasis sukuk. Hal itu dilakukan dalam rangka meningkatkan jumlah investor ritel. OJK perlu mendorong pelaku pasar untuk menerbitkan reksa dana syariah berbasis satu atau lebih sukuk. Jenis reksa dana ini dapat mendorong peningkatan penerbitan sukuk karena reksa dana syariah ini diterbitkan bersamaan dengan penerbitan sukuk korporasi atau sukuk negara yang akan menjadi basis portofolio reksa dana ini. Selanjutnya reksa dana jenis ini ditawarkan kepada masyarakat luas sehingga dapat mendorong kepemilikan sukuk oleh investor ritel.

4) Penerbitan regulasi terkait produk investasi syariah baru. Dalam rangka meningkatkan pertumbuhan industri pasar modal syariah, perkembangan produk investasi syariah perlu didukung adanya pengembangan jenis produk investasi yang baru. Produk investasi yang akan dikembangkan tersebut antara lain reksa dana syariah berbasis efek luar negeri, Dana Investasi Real Estate Syariah, reksa dana berbasis proyek, dan bundling product keuangan syariah. Untuk memberikan landasan hukum dan keyakinan pelaku pasar akan produk baru tersebut, perlu adanya regulasi yang mengaturnya.

5) Kajian naskah akademis dalam rangka penyusunan rancangan undang-undang tentang efek syariah.

\section{Mengupayakan Insentif untuk Produk Syariah}

Berdasarkan data statistik, market share produk syariah, khususnya nilai sukuk dan reksa dana syariah masih berada pada kisaran 5\% dibandingkan dengan total produk konvensional dan syariah. Dalam rangka mempercepat pertumbuhan dan meningkatkan porsi produk pasar modal syariah, perlu adanya stimulus atas produk syariah terse- 
but. Oleh karena itu, perlu diupayakan adanya insentif antara lain berupa relaksasi aturan dan potongan pungutan bagi penerbitan produk syariah di pasar modal. Insentif tersebut diberikan sebagai kompensasi atas upaya lebih yang dilakukan dalam penerbitan produk syariah jika dibandingkan dengan penerbitan produk konvensional. Mengingat pasar modal syariah merupakan industri yang sedang berkembang, maka perlu diupayakan adanya insentif berupa potongan atas pungutan sebagaimana dimaksud pada ketentuan di atas. Potongan tersebut antara lain dapat berupa potongan atas biaya perizinan, biaya pendaftaran, dan biaya tahunan, yang diberikan kepada pihak yang terlibat dalam penerbitan efek syariah serta pihak yang memberikan layanan syariah di pasar modal. ${ }^{14}$

\section{Memperkuat Peran Pelaku Pasar di Pasar Modal Syariah}

Dalam praktik pasar modal syariah terdapat banyak pihak yang berperan penting dalam penerbitan efek syariah, antara lain pihak yang memastikan pemenuhan prinsip syariah suatu produk, wali amanat dalam penerbitan sukuk, dan manajer investasi yang berperan dalam penerbitan reksa dana syariah. Terkait dengan hal tersebut, program untuk memperkuat peran pelaku pasar modal syariah dapat diwujudkan dalam rencana aksi sebagai beriku: 1) penerbitan aturan terkait ahli syariah (DPS) di pasar modal; dan 2) penerbitan aturan terkait lembaga penunjang di pasar modal syariah dan perusahaan efek.

\section{Memperkuat Landasan Hukum bagi Transaksi Efek Syariah}

Dalam Fatwa DSN Nomor 40 tahun 2003 tentang Pasar Modal dan Pedoman Umum Penerapan Prinsip Syariah di Pasar Modal, DSN-MUI telah mengatur jenis transaksi perdagangan efek yang dilarang. Menurut fatwa tersebut, pelaksanaan transaksi harus dilakukan menurut prinsip kehati-hatian serta menghindari spekulasi dan manipulasi yang mengandung unsur dharar, gharar, riba, maisir, risywah, maksiat dan kezhaliman. Selanjutnya, DSN-MUI telah menerbitkan Fatwa No. 80

14 Dalam pasal 17 ayat (3) Peraturan Pemerintah Nomor 11 Tahun 2014 tentang Pungutan oleh OJK, disebutkan bahwa "Dalam hal OJK akan atau sedang mengembangkan industri, jenis layanan, atau produk keuangan tertentu, baik secara nasional ataupun di daerah tertentu, OJK dapat mengenakan Pungutan paling rendah sebesar 25\% dari besaran pungutan sebagaimana ditetapkan..." 
tahun 2011 tentang Penerapan Prinsip Syariah dalam Mekanisme Perdagangan Efek Bersifat Ekuitas di Pasar Reguler Bursa Efek. Terkait dengan hal tersebut di atas, dalam peta konsep ini telah ditetapkan program-program untuk memperkuat landasan hukum bagi transaksi efek syariah sehingga dapat melahirkan peraturan mengenai pasar modal syariah yang dapat dikeluarkan oleh Otoritas Jasa Keuangan.

Berdasarkan pemaparan di atas, penulis dapat merumuskan bahwa yang melatarbelakangi lahirnya POJK tentang Penerapan Prinsip Syariah di Pasar Modal, yaitu untuk menguatkan pengaturan atas produk, lembaga, dan profesi terkait dengan pasar modal syariah, yang terdiri dari: 1) penguatan terhadap kerangka hukum untuk penerbitan efek syariah; 2) mengupayakan insentif untuk produk syariah; 3) memperkuat peran pelaku pasar di pasar modal syariah; dan 4) memperkuat landasan hukum bagi transaksi efek syariah.

\section{Peraturan Otoritas Jasa Keuangan tentang Penerapan Prinsip Syariah di Pasar Modal}

Dalam rangka pengembangan pasar modal syariah agar dapat tumbuh stabil dan berkelanjutan diperlukan pengembangan infrastruktur pasar yang memadai. Salah satu infrastruktur pasar yang penting adalah tersedianya regulasi yang jelas, mudah dipahami, dan dapat dilaksanakan sehingga regulasi tersebut menjadi regulasi yang dapat diterima pasar (market friendly).

Dinamika perkembangan Pasar Modal syariah menuntut adanya penyempurnaan Peraturan Nomor IX.A.13, Lampiran Keputusan Ketua Badan Pengawas Pasar Modal dan Lembaga Keuangan Nomor: KEP181/BL/2009 tanggal 30 Juni 2009 tentang Penerbitan Efek Syariah, agar sesuai dengan kebutuhan industri pasar modal syariah, praktik yang berlaku umum, dan standar internasional.

Peraturan Otoritas Jasa Keuangan (POJK) Nomor 15/POJK.04/ 2015 tentang Penerapan Prinsip Syariah di Pasar Modal, ini menyempurnakan Peraturan Nomor IX.A.13, Lampiran Keputusan Ketua Badan Pengawas Pasar Modal dan Lembaga Keuangan Nomor Kep-181/BL/ 2009 tanggal 30 Juni 2009 tentang Penerbitan Efek Syariah, yang mengatur antara lain penerapan Prinsip Syariah di pasar modal dalam kegiatan syariah di pasar modal dan/atau kegiatan dan jenis usaha, cara pengelolaan usaha yang dilakukan, serta produk atau jasa yang diterbitkan berdasarkan prinsip syariah. Beberapa pokok penyempur- 
naan dalam Peraturan Otoritas Jasa Keuangan ini antara lain meliputi jenis kegiatan usaha yang bertentangan dengan Prinsip Syariah di pasar modal, transaksi yang bertentangan dengan prinsip syariah di pasar modal, kewajiban bagi pihak yang melakukan kegiatan syariah di pasar modal, dan laporan pemenuhan prinsip syariah di pasar modal.15

Peraturan Otoritas Jasa Keuangan Nomor 15/POJK.04/-2015 tentang Penerapan Prinsip Syariah Di Pasar Modal tersebut di dalamnya mencakup beberapa poin penting, seperti:

a. Ketentuan Umum (definisi operasional);

b. Pihak yang Melakukan Kegiatan Syariah di Pasar Modal;

c. Pelaporan;

d. Ketentuan Lain-lain;

e. Ketentuan Sanksi;

f. Ketentuan Penutup; dan

g. Penjelasan atas Peraturan Otoritas Jasa Keuangan Nomor 15/POJK.04/2015 tentang Penerapan Prinsip Syariah di Pasar Modal.

Pada saat Peraturan Otoritas Jasa Keuangan ini mulai berlaku, angka 1 Peraturan Nomor IX.A.13 tentang Penerbitan Efek Syariah, Lampiran Keputusan Ketua Badan Pengawas Pasar Modal dan Lembaga Keuangan Nomor: Kep-181/BL/2009 tanggal 30 Juni 2009 tentang Penerbitan Efek Syariah dicabut dan dinyatakan tidak berlaku.16 Peraturan yang dibuat oleh OJK ini merupakan peraturan pelaksana teknis yang mengatur tentang Penerapan Prinsip Syariah Di Pasar Modal dari Undang-Undang Nomor 8 Tahun 1995 tentang Pasar Modal dan Undang-Undang Nomor 21 Tahun 2011 tentang Otoritas Jasa Keuangan.

\section{Penutup}

Lahirnya Perat uran Otoritas Jasa Keuangan Nomor 15/POJK.04/ 2015 tentang Penerapan Prinsip Syariah di Pasar Modal, dilatarbelakangi oleh salah satu program yang direncanakan oleh 0JK terkait dengan "Penguatan Pengaturan atas Produk, Lembaga, dan Profesi Terkait Pasar Modal Syariah". Arah pengembangan tersebut dilakukan

15 Lihat Penjelasan Umum dalam Peraturan Otoritas Jasa Keuangan Nomor 15/POJK.04/2015 tentang Penerapan Prinsip Syariah Di Pasar Modal.

16 Bab VI Ketentuan Penutup Pasal 16 Peraturan Otoritas Jasa Keuangan Nomor 15/POJK.04/2015 tentang Penerapan Prinsip Syariah Di Pasar Modal. 
melalui 4 (empat) program berikut: 1) memperkuat Kerangka Hukum untuk Penerbitan Efek Syariah; 2) mengupayakan Insentif untuk Produk Syariah; 3) memperkuat Peran Pelaku Pasar di Pasar Modal Syariah; dan 4) memperkuat Landasan Hukum bagi Transaksi Efek Syariah.

Peraturan Otoritas Jasa Keuangan (POJK) Nomor 15/POJK.04/ 2015 tentang Penerapan Prinsip Syariah di Pasar Modal, ini menyempurnakan Peraturan Nomor IX.A.13, Lampiran Keputusan Ketua Badan Pengawas Pasar Modal dan Lembaga Keuangan Nomor Kep-181/BL/ 2009 tanggal 30 Juni 2009 tentang Penerbitan Efek Syariah. Kemudian pada saat Peraturan Otoritas Jasa Keuangan ini mulai berlaku, angka 1 Peraturan Nomor IX.A.13 tentang Penerbitan Efek Syariah, Lampiran Keputusan Ketua Badan Pengawas Pasar Modal dan Lembaga Keuangan Nomor: Kep-181/BL/2009 tanggal 30 Juni 2009 tentang Penerbitan Efek Syariah dicabut dan dinyatakan tidak berlaku.

\section{DAFTAR PUSTAKA}

Draft Peraturan Otoritas Jasa Keuangan Nomor ......./POJK.04/2014 tentang Penerbitan Sukuk.

Fatwa Dewan Syariah Nasional Nomor 20/DSN-MUI/IX/2000 tentang Pedoman Pelaksanaan Investasi untuk Reksa Dana Syariah.

Fatwa Dewan Syariah Nasional Nomor 69/DSN-MUI/VI/2008 tentang Surat Berharga Syariah Negara.

Fatwa DSN Nomor 40/DSN-MUI/X/2003 tentang Pasar Modal dan Pedoman Umum Penerapan Syariah di Bidang Pasar Modal.

Cahyono, Jaka E. 2000. Cara Jitu Memilih Untung dari Reksa Dana. Jakarta: Elex Media Komputindo.

Peraturan Departemen Keuangan Republik Indonesia Badan Pengawas Pasar Modal dan Lembaga Keuangan No. IX.A.13 tentang Penerbitan Efek Syariah.

Peraturan Departemen Keuangan Republik Indonesia Badan Pengawas Pasar Modal dan Lembaga Keuangan No. IX.A.14 tentang Akadakad yang Digunakan dalam Penerbitan Efek Syariah. 
Peraturan Departemen Keuangan Republik Indonesia Badan Pengawas Pasar Modal dan Lembaga Keuangan No. II.K.1 tentang Kriteria dan Penerbitan Daftar Efek Syariah.

Peraturan Otoritas Jasa Keuangan Nomor 15/POJK.04/2015 tentang Penerapan Prinsip Syariah di Pasar Modal.

Siamet, Dahlan. 2004. Manajemen Lembaga Keuangan. Jakarta: Lembaga Penerbit Fakultas Ekonomi Universitas Indonesia.

Sitompul, Asri. 2000. Reksa Dana: Pengantar dan Pengenalan Umum. Bandung: Cintra Aditya Bakti.

Soemitra, Andri. 2014. Bank dan Lembaga Keuangan Syariah. Jakarta: Kencana.

Susilo, Y. Sri., dkk. 2004. Bank dan Lembaga Keuangan Lain. Jakarta: Salemba Empat.

Tim Penyunting. 2014. Himpunan Fatwa Keuangan Syariah (Dewan Syariah Nasional MUI). Jakarta: Erlangga.

Tim Penyusun Direktorat Pasar Modal Syariah Otoritas Jasa Keuangan. 2015. Roadmap Pasar Modal Syariah 2015-2019. Jakarta: Direktorat Pasar Modal Syariah Otoritas Jasa Keuangan.

Darmadji, Tjipto dkk. 2000. Pasar Modal di Indonesia. Jakarta: Salemba Empat.

Undang-Undang Nomor 21 Tahun 2011 tentang Otoritas Jasa Keuangan.

Undang-Undang Nomor 8 Tahun 1995 tentang Pasar Modal. 